\title{
Nutritional Regulation of IGF-I Expression during Brain Development in Mice
}

\author{
ALI S. CALIKOGLU, AYSEN F. KARAYAL, AND A. JOSEPH D'ERCOLE \\ Department of Pediatrics, University of North Carolina at Chapel Hill, Chapel Hill, North Carolina \\ 27599-7220, U.S.A.
}

ABSTRACT

\begin{abstract}
ABST
Although brain injury induced by undernutrition during early
life is well described, the mechanisms that mediate the effects of
undernutrition on brain development are not known. IGF-I plays
an important role in the stimulation of postnatal somatic and
brain growth. We have shown that IGF-I overexpression in brain
ameliorates the effects of undernutrition on early postnatal brain
growth, and thus, we postulated that alterations in IGF-I expres-
sion or action mediate the pathogenesis of malnutrition-induced
brain injury. To begin to address this issue we evaluated the
influence of undernutrition on brain IGF-I expression during
early postnatal development in mice. Undernutrition was induced
in mice by separating half of the pups in each litter from their
lactating dams for a defined period each day. Pups were killed at
postnatal day (P) 7 , P14, P21, and P28. The changes in IGF-I
mRNA were quantified by ribonuclease protection assay. At P7
IGF-I mRNA abundance in undernourished animals was in-
creased in cerebral cortex (223\% of controls), but decreased in
diencephalon (36\% of controls). At P14, IGF-I mRNA abun-
dance was increased in diencephalon (230\% of controls). Al-
though there were no other statistically significant alterations of
IGF-I mRNA in undernourished mice, IGF-I abundance in the
\end{abstract}
cerebral cortex appeared increased at P14 (142\% of controls), and in cerebellum it was consistently but modestly decreased (78 and $59 \%$ of controls) from P7 to P21, respectively. We conclude that nutrition regulates murine brain IGF-I expression in a developmentally specific fashion that is dependent on the region of expression. Importantly, the influence of undernutrition on IGF-I expression is markedly different in the brain than in liver, where nutritional deficiency profoundly decreases IGF-I expression. We speculate that the relative preservation of or increases in regional brain IGF-I expression explain, at least in part, the well-known finding that undernutrition during early postnatal development has less marked growth-retarding effects on the brain than it does on the soma. (Pediatr Res 49: 197-202, 2001)
IGFBP-1, IGF b
P, postnatal day
CB, cerebellum
RNase, ribonuclease
CTX, cerebral cortex
DN, diencephalon

In rodents, undernutrition during early life results in reduced brain weight, reduced total cell number, reduced and delayed myelination, increased density of cortical neurons, loss of axon terminals in the cerebral cortex, and substantial deficits in the synapse-to-neuron ratio in some brain regions, indicating a reduction in the total synapse number $(1-7)$. In addition to the duration and severity of undernutrition, the developmental time when undernutrition occurs is crucial to the degree of injury (1, $2,8)$. For example, a prolonged moderately severe period of undernutrition during the adult life in the rat causes only a small reduction in brain weight that is reversible. In contrast, short periods of undernutrition during early postnatal rat development can cause permanent anatomic and functional brain deficits. There are, therefore, critical or vulnerable periods

\footnotetext{
Received June 20, 2000; accepted September 18, 2000.

Correspondence and reprint requests: Ali S. Calikoglu, M.D., Department of Pediatrics, CB\# 7220, University of North Carolina, Chapel Hill, NC 27599-7220, U.S.A. Supported by NIH grants DK-02506 (A.S.C.) and HD-08299 (A.J.D.).
}

during brain development. In rodents, this critical period of brain development occurs during suckling, i.e. the first $3 \mathrm{wk}$ of postnatal life $(1,2,8)$.

The mechanisms that mediate the effects of undernutrition on brain development are not known. A number of lines of evidence suggest that a reduction in IGF-I expression or action has a major role. 1) Both in man and experimental animals, reduced protein or energy intake lowers IGF-I expression in many tissues $(9,10)$. Liver IGF-I mRNA abundance is extremely sensitive to reduced nutrition $(9,10)$, and because liver is the major source of circulating IGF-I (11), undernutrition can profoundly reduce circulating IGF-I $(9,12)$. 2) IGF-I mRNA expression peaks in multiple brain regions during the first $3 \mathrm{wk}$ of life in rodents (13), the same development time when the rodent brain is most vulnerable to nutritional insult (8). 3) Transgenic mice that overexpress IGF-I exhibit marked brain overgrowth postnatally (14-17), whereas transgenic mice with ectopic brain expression of IGFBP-1, an inhibitor of IGF action, and mice with ablated IGF-I gene expression have 
brain growth retardation $(18,19) .4)$ Malnutrition during brain development results in a marked decrease in myelination (7), and IGF-I is a potent stimulator of brain myelination $(16,20)$. 5) IGF-I overexpression in brain ameliorates the effects of undernutrition on early postnatal brain growth, whereas ectopic IGFBP-1 expression in brain exacerbates these effects (21).

We therefore hypothesized that nutritional status has a role in the regulation of brain IGF-I expression. In this study, we evaluated the influence of undernutrition on brain IGF-I expression during preweaning development. Because brain IGF-I expression is developmentally regulated and differs among brain regions, we performed our studies in several major regions of the brain.

\section{METHODS}

Mice and experimental design. Eight-week-old C57/B6 female mice were mated with male mice of the same strain, and the onset of pregnancy was assessed by daily inspection for vaginal plugs. Once pregnancies were confirmed by weight gain (generally at $12 \mathrm{~d}$ of gestation), mice were caged individually and monitored daily for delivery (termed P0). Newborn litters were adjusted to 7 to 8 pups. Undernutrition was induced by separating half the pups in each litter from their lactating dams for defined periods each day ( $4 \mathrm{~h}$ on $\mathrm{P} 1,8 \mathrm{~h}$ on $\mathrm{P} 2$, and $12 \mathrm{~h}$ thereafter). This method has the advantage of providing littermate-control, well-nourished pups to compare with the undernourished pups. In rats, this method produces a similar degree of undernutrition to that produced by other methods (22), such as fasting the dam, feeding the dam suboptimal diet, or increasing litter size to diminish food intake per pup. All mice were housed in a temperature- and light-controlled room and weighed each day to insure that control mice were subjected to the same degree of handling. Pups were killed at P7, P10, P14, P21, and P28. These time points coincide with the period when the rodent brain is most vulnerable to nutritional insult and when IGF-I mRNA expression peaks in brain. Brains were rapidly removed and dissected into three brain regions: $\mathrm{CB}, \mathrm{CTX}$, and $\mathrm{DN}$. The whole brains and their regions were weighed, frozen separately in liquid nitrogen, and stored at $-80^{\circ} \mathrm{C}$ until RNA was extracted. All animal procedures were approved by the Institutional Animal Care and Use Committee at the University of North Carolina, Chapel Hill.

$\boldsymbol{R} \boldsymbol{N} \boldsymbol{A}$ extraction and hybridization probes. Total RNA was extracted with a single-step method using a commercial kit (Trizol, Life Sciences, Grand Island, NY, U.S.A.). A mouse IGF-I riboprobe was generated with PCR using primers specific for mouse IGF-I exon 3 cDNA. This probe gives a protected fragment of 170 nucleotides in RNase protection assay. The consensus sequence of T3 and T7 RNA polymerase promoters was included in the primers to generate sense or antisense transcripts, respectively. Biotin-labeled IGF-I antisense RNA was synthesized with T7 polymerase (Promega Corp., Madison, WI, U.S.A.) using biotin-14-CTP (Ambion Corp., Austin, TX, U.S.A.). A mouse cyclophilin riboprobe (Ambion Corp), giving a 102-nucleotide protected fragment also was labeled with biotin.
RNase protection assay. RNase protection assay was performed using a commercial kit (RPA II, Ambion Corp). Hybridization of $30 \mu \mathrm{g}$ of total RNA obtained from target tissues was performed by incubation with 3 fmol of biotin-labeled IGF-I and cyclophilin antisense probes in hybridization buffer (80\% deionized formamide, $100 \mathrm{mM}$ sodium citrate, $\mathrm{pH} 6.4$, $300 \mathrm{mM}$ sodium acetate, $\mathrm{pH} 6.4,1 \mathrm{mM}$ EDTA) at $45^{\circ} \mathrm{C}$ for 16-18 h. After hybridization, an RNase anti-RNase T1 mixture (1:100 dilution) in RNase digestion buffer was added to all tubes. After a $30-\mathrm{min}$ incubation at $37^{\circ} \mathrm{C}$, samples were treated with a stop solution to inactivate and precipitate the RNase. The samples were incubated for $30 \mathrm{~min}$ at $-20^{\circ} \mathrm{C}$ and microcentrifuged for $30 \mathrm{~min}$ at maximum speed at $4^{\circ} \mathrm{C}$, the supernatant was removed, and the pellets were dissolved in gel loading. Samples then were heated for $3-4 \mathrm{~min}$ at $95^{\circ} \mathrm{C}$, loaded onto a denaturing polyacrylamide gel (5\% polyacrylamide, 8 $\mathrm{M}$ urea gel), and run at approximately $250 \mathrm{~V}$ for about $1 \mathrm{~h}$ in TBE buffer (0.09 M Tris, 0.09 M boric acid, and $1 \mathrm{mM}$ EDTA). Protected hybrids in the gel then were transferred to nylon membranes by electroblotting. Pilot experiments confirmed that the concentrations of probes were in molar excess. Nonspecific hybridization and the completeness of digestion were confirmed by including yeast RNA (in amounts equal to experimental samples) in each experiment. To detect signals, the protocols recommended by the manufacturer (Ambion Corp) were followed. Each blot was exposed repeatedly for different periods of times with Biomax MR film (Kodak, Rochester, NY, U.S.A.), and each band was quantified densitometrically using an ImagePro plus Imaging Analysis System (Image Pro, Media Cybernetic, Silver Spring, MD, U.S.A.), normalized to cyclophilin and expressed as the ratio of the band of interest to the cyclophilin band from the same RNA preparation. For ease in reporting results, this ratio of sample IGF-I signal to cyclophilin signal is simply termed units.

Statistical analysis. Data are expressed as the mean \pm SEM. Comparisons were made by unpaired $t$ test using Stat View-II program (Abacus Concepts, Berkeley, CA, U.S.A.).

\section{RESULTS}

Body and brain weights. Each experimental group consisted of 5-8 pups, and the number of deaths did not differ significantly between undernourished and control groups (11 and 9\%, respectively). There was no difference in body weight between groups at birth $(1.46 \pm 0.01 \mathrm{~g}$ and $1.51 \pm 0.01 \mathrm{~g}$ in undernourished and control mice, respectively; $p=\mathrm{NS})$. At P3, body weights of undernourished mice were significantly lower than their well-fed littermates $(1.85 \pm 0.01 \mathrm{~g}$ and $2.16 \pm$ $0.03 \mathrm{~g}$, respectively; $p<0.001)$. Undernourished mice grew more slowly than well-fed controls throughout the period of study, and the decrement in growth rate was relatively constant throughout the study period, being reduced by $72 \%$ between $\mathrm{P} 0$ and P14 and 67.2\% between P14 and P28. At P28, undernourished mice had weights that were $39.7 \%$ of those in control mice (Fig. 1, middle).

As expected, the changes in the brain size of undernourished mice were not as severe as were those in their body weight. The decrease in brain weight was apparent in undernourished 
mice as early as P7, the earliest time brains were weighed $(0.175 \pm 0.017 \mathrm{~g}$ and $0.260 \pm 0.022 \mathrm{~g}$ in undernourished and well-fed controls, respectively; $p<0.001$; Fig. 1, top). At P14, brain weight of undernourished mice was $69.7 \%$ of well-fed controls $(0.282 \pm 0.046 \mathrm{~g}$ and $0.403+0.023 \mathrm{~g}$, respectively; $p<0.001)$. At $\mathrm{P} 28$, brains of undernourished mice were reduced by $19.2 \%$ compared with well-fed controls $(0.363 \pm$ $0.017 \mathrm{~g}$ and $0.449 \pm 0.019 \mathrm{~g}$, respectively; $p<0.001)$. Because undernourished mice demonstrated a relatively greater reduction in body weight than brain weight, they had a higher brain/body weight ratio compared with well-fed controls at all times studied (Fig. 1, bottom), a finding indicative of the relatively preserved brain growth that is characteristic of early postnatal undernutrition.
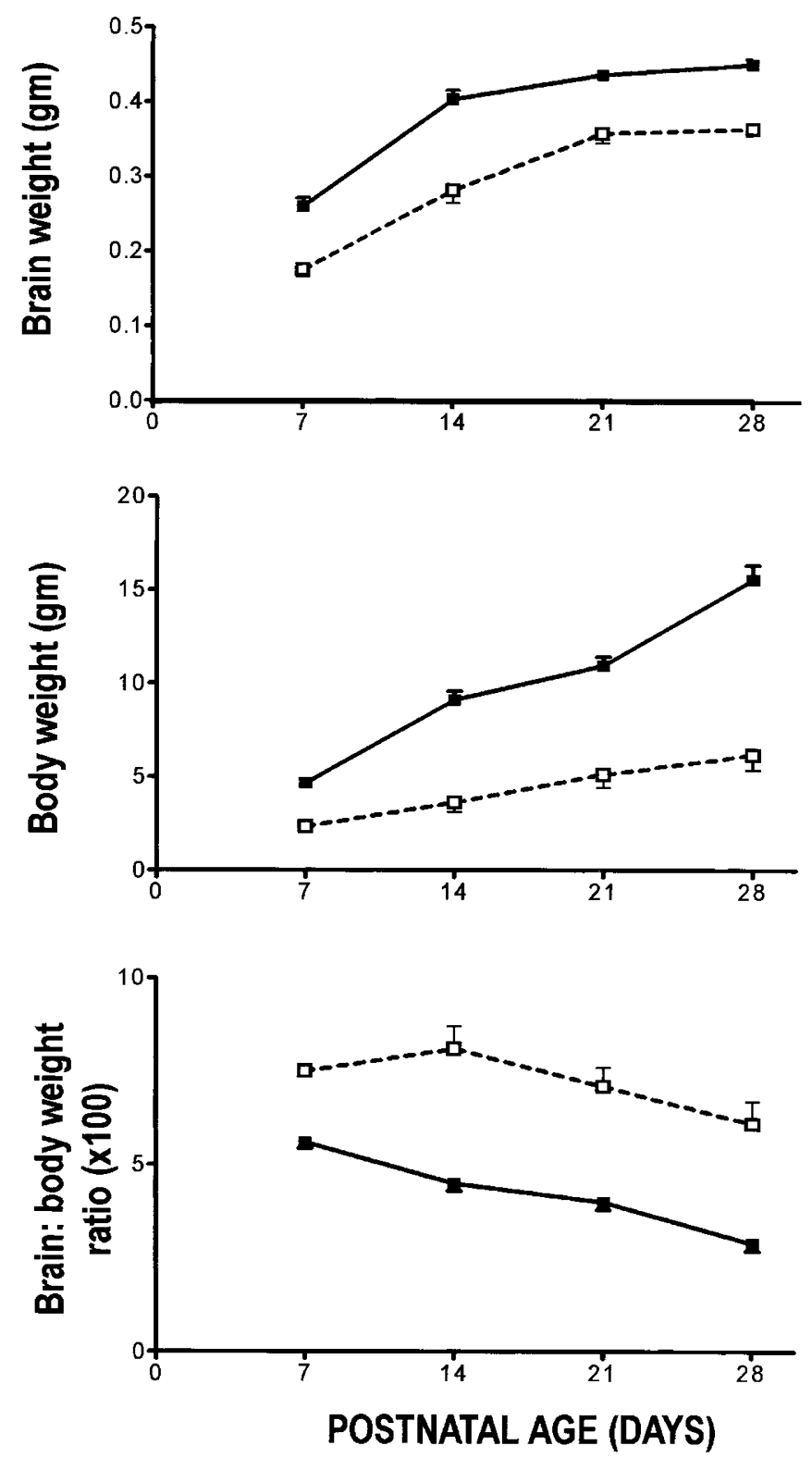

Fig. 1. Brain weight (Top), body weight (Middle) and brain/body weight ratio (Bottom) during postnatal development in well-fed (ם) and undernourished $(\square)$ mice. Data are mean \pm SEM. $n$ for each data point is $6-9$ animals. $p<$ 0.001 , compared with well-fed controls at each time point in all figures.
To determine the effects of undernutrition on distinct brain regions, we also measured the weights of three major brain regions, $\mathrm{CTX}, \mathrm{DN}$, and $\mathrm{CB}$, during development. In well-fed mice, $\mathrm{CB}$ and CTX exhibited significant postnatal growth, and their weights increased 3.1- and 2.3-fold, respectively, between P7 and P28. DN, however, had little growth (1.1-fold increase) in the same period (Fig. 2). These findings reflect the fact that in mice significant CB and CTX growth occurs in postnatally, whereas DN growth is nearly complete during fetal life.

Similar to the changes in whole brain, CTX and CB demonstrated significant growth retardation in undernourished animals (Fig. 2). The CB was significantly smaller in undernourished mice by at P7 $(8.33 \pm 0.33 \mathrm{mg}$, compared with $15.50 \pm$

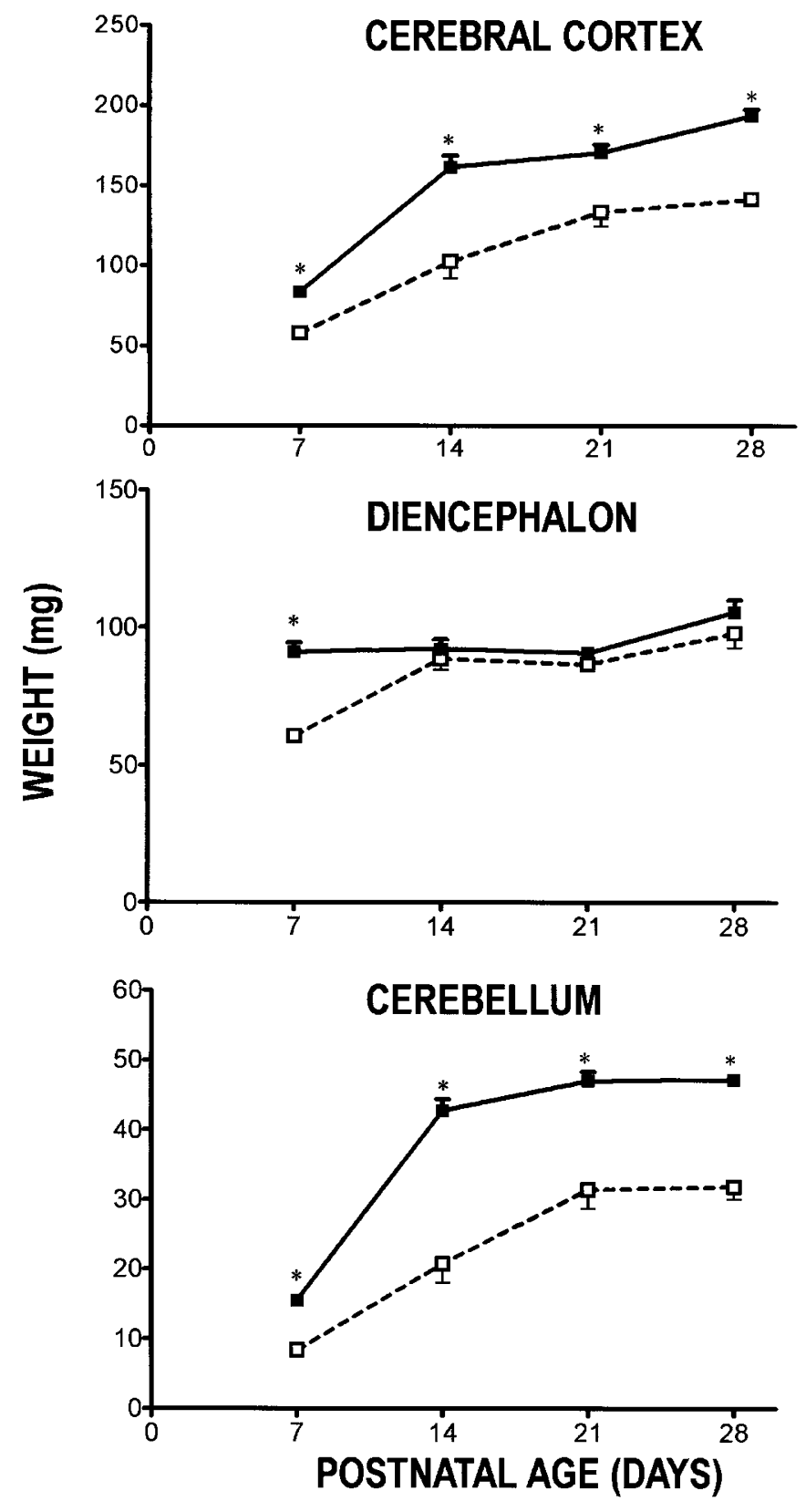

Fig. 2. CTX (Top), DN (Middle), and CB weight (Bottom) during postnatal development in well-fed $(\square)$ and undernourished $(\square)$ mice. Data are mean \pm SEM. $n$ for each data point is $6-9$ animals. ${ }^{*} p<0.001$ compared with well-fed controls. 
$0.67 \mathrm{mg}$ in well-fed controls; $p<0.001$ ), and this difference persisted until P28 $(31.8 \pm 1.74 \mathrm{mg}$, compared with $47.2 \pm$ $0.83 \mathrm{mg}$ in control; $p<0.001$ ) when CB weight was $67.3 \%$ of that in controls. CTX demonstrated similar changes. The CTX was smaller in undernourished mice at P7 $(57.8 \pm 1.08 \mathrm{mg}$, compared with $83.8 \pm 3.04 \mathrm{mg}$ in well-fed mice; $p<0.001$ ) and at P28 (141.4 $\pm 4.12 \mathrm{mg}$ and $193.3 \pm 4.18 \mathrm{mg}$, respectively; $p<0.01$ ), when its weight was $73.1 \%$ that of well-fed controls. DN demonstrated a different growth pattern in undernourished animals. At P7, DN was significantly smaller in undernourished mice $(60.5 \pm 0.88 \mathrm{mg}$, compared with $91.0 \pm$ 3.53 in controls; $p<0.001$ ), but the difference in DN size between undernourished and well-fed mice were not significant at P14 (88.6 \pm 3.98 , compared with $92.3 \pm 3.38 \mathrm{mg}$ in control) or at P28 $(98.0 \pm 5.28 \mathrm{mg}$, compared with $105.7 \pm 4.39$ in controls). These observations indicate that postnatal growth of $\mathrm{CB}$ and CTX is vulnerable to nutritional insult. Postnatal growth of $\mathrm{DN}$, on the other hand, appears to be delayed by undernutrition, but its weight is relatively preserved despite undernutrition.

IGF-I mRNA expression. Compared with well-fed controls at P7 (Figs. 3 and 4), IGF-I mRNA abundance in CTX in undernourished mice was $223 \%$ of well-fed controls $(0.39 \pm$ 0.11 units, compared with $0.89 \pm 0.09$ units in well-fed controls; $p<0.01$ ). At P14, IGF-I mRNA tended to be increased in undernourished mice (142\% of well-fed controls), but this was not significant $(0.41 \pm 0.09$ units and $0.59 \pm 0.18$ units, respectively; $p=\mathrm{NS}$ ). At P21 and P28, CTX IGF-I mRNA abundance was similar in both groups of mice (P21, $9.51 \pm 1.86$ units in undernourished mice, compared with 10.0 \pm 2.46 units in well-fed controls; P28, $3.52 \pm 0.51$ units in undernourished mice, compared with $3.48 \pm 0.55$ units in well-fed controls; $p=$ NS).

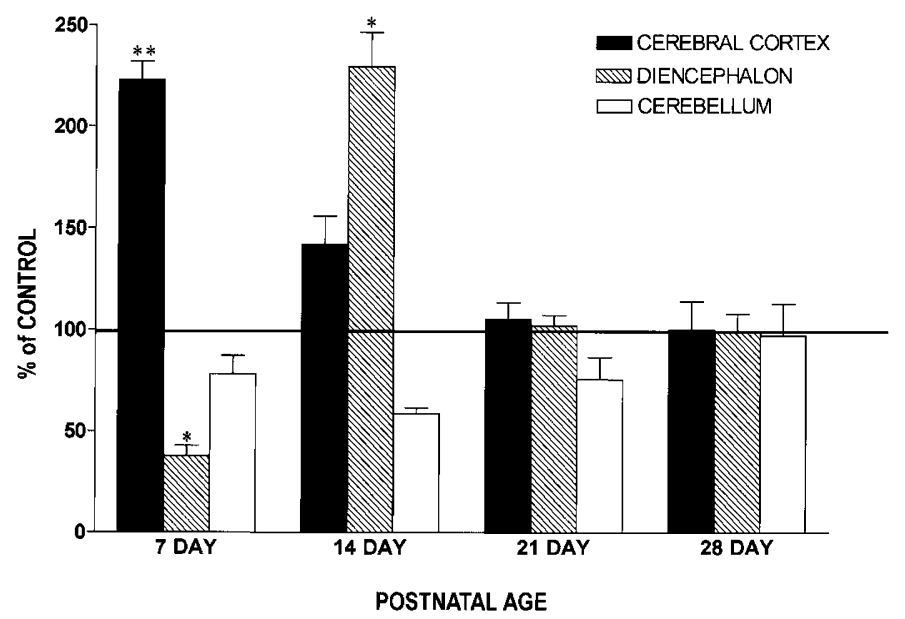

Fig. 4. Quantification of RNase protection assay. IGF-I mRNA abundance in the CTX, DN, and CB is expressed as the percentage of well-fed control mice. The values represent mean \pm SEM from $4-6$ animals. $* p<0.05 ; * p<0.01$, compared with well-fed controls.

In $\mathrm{CB}$, there were no differences in IGF-I mRNA abundance between groups at any time studied (P7, $0.31 \pm 0.09$ units in undernourished mice, compared with $0.40 \pm 0.03$ units in controls; P14, $0.34 \pm 0.10$ units in undernourished mice, compared with $0.58 \pm 0.15$ units in well-fed controls; P21, $2.05 \pm 0.5$ units in undernourished mice, compared with 2.71 \pm 0.8 units in well-fed controls; P28, $0.82 \pm 0.13$ in undernourished mice, compared with $0.85 \pm 0.10$ units in well-fed controls; $p=\mathrm{NS}$ ).

IGF-I mRNA abundance in DN of undernourished animals showed a different pattern. The abundance of IGF-I mRNA at P7 was decreased by $62 \%$ in undernourished mice $(0.77 \pm 0.21$ units, compared with $2.04 \pm 0.30$ units in controls; $p<0.01$ ),

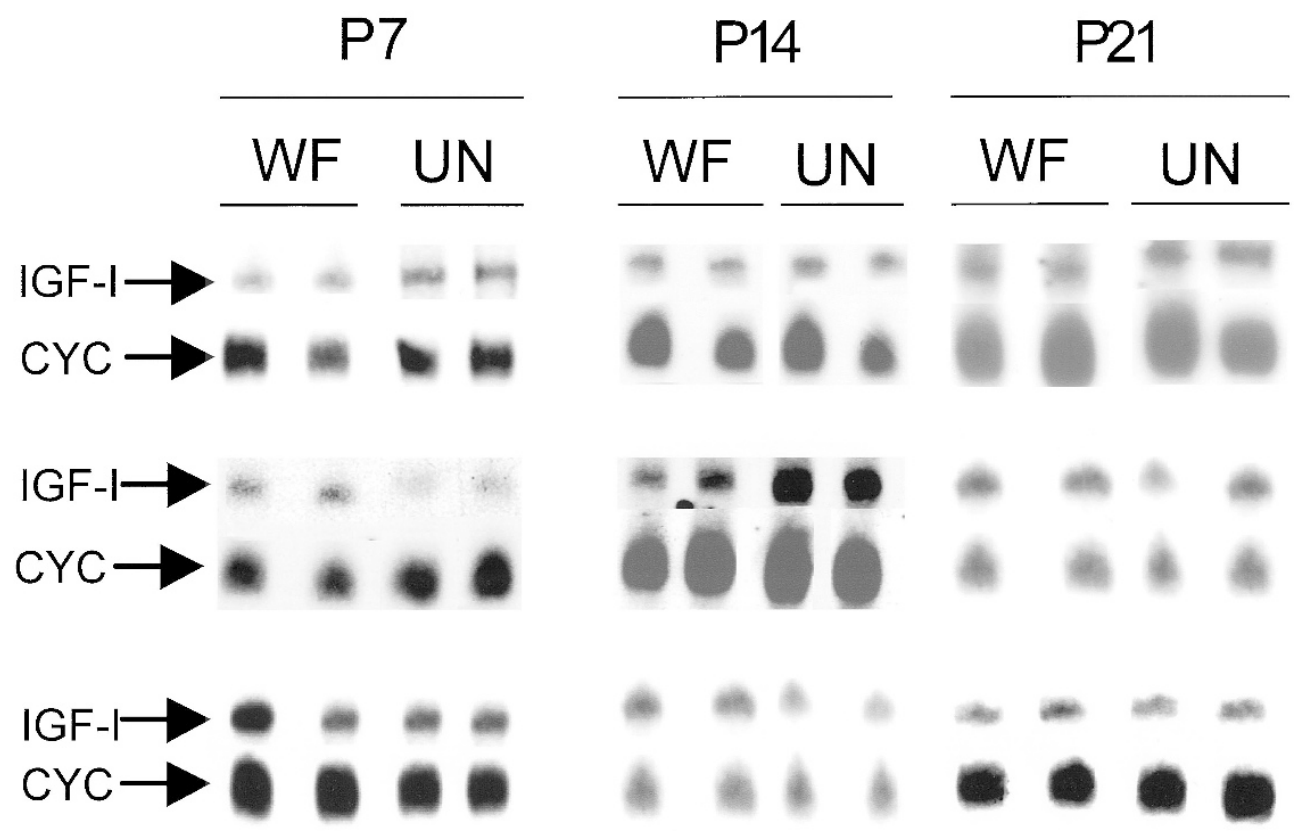

Fig. 3. IGF-I mRNA abundance in the CTX (Top), DN (Middle), and CB (Bottom) of well-fed (WF) and undernourished (UN) mice at P7, P14, and P21. Photomicrographs of representative gels from RNase protection assay are shown. Each lane was loaded with $30 \mu \mathrm{g}$ of total RNA. The upper arrow indicates the 170-nucleotide IGF-I mRNA protected fragment and lower arrow indicates the 102-nucleotide cyclophilin $(C Y C)$ protected fragment. Note that the gels shown for each age come from separate experiments, because experiments were performed with mRNA samples from the mice of the same age. 
but increased by $130 \%$ at P14 (5.42 \pm 1.4 units, compared with $2.36 \pm 0.5$ units in controls; $p<0.05)$. There were no differences at P21 or P28 (P21, $0.24 \pm 0.09$ units in undernourished mice, compared with $0.23 \pm 0.03$ units in controls; P28, $9.12 \pm 1.29$ units in undernourished mice, compared with $9.16 \pm 0.81$ units; $p=\mathrm{NS}$ ).

\section{DISCUSSION}

We have shown that undernutrition influences brain IGF-I expression in a unique fashion that appears to be dependent both on developmental age and the region of expression. Most studies of nutritional regulation of IGF-I have focused on the liver, and all such studies, including the relatively few that investigated nonhepatic tissues (other than the brain), have shown that undernutrition decreases IGF-I mRNA or protein abundance $(9,10,12,23)$. The increases we observed in CTX and DN IGF-I mRNA during the first 2 wk of postnatal life, therefore, were surprising. In addition, other than a decrease in IGF-I mRNA in P7 DN, undernutrition did not significantly reduce brain IGF-I mRNA expression at any age studied. The changes in IGF-I mRNA abundance in DN appeared to parallel those in DN weight. Undernourished mice had lower IGF-I mRNA abundance at $\mathrm{P} 7$ when DN demonstrated growth retardation; and the increased IGF-I mRNA expression in P14 coincided with the catch-up growth of DN. Each of these findings indicates that nutritional regulation of IGF-I expression in brain differs from that in other tissues. Although other mechanisms such as changes in the expression of IGF binding proteins or type I IGF receptor could play role, these data suggest that the increase in or preservation of IGF-I expression in brain during undernutrition accounts in whole or part for the relative resistance of the neonatal brain to the growthretardation induced by undernutrition.

Fasting or protein and energy restriction can, depending on its duration or severity, result in marked decreases in hepatic IGF-I mRNA abundance in both adult and newborn rats (2325). There are few studies of the influence of nutritional deprivation on brain IGF-I mRNA expression, and none have been performed during early postnatal development. In one study, fasting of young adult rats for $48 \mathrm{~h}$ was reported to decrease IGF-I mRNA levels in whole brain by $30 \%$ (10). However, in another study, fasting for $72 \mathrm{~h}$ or protein restriction for $1 \mathrm{wk}$ produced no change in whole brain IGF-I expression (26). Consistent with the latter studies, we observed no significant influence of undernutrition on brain IGF-I expression after the second week of life, i.e. at P21 and P28. We have no certain explanation for the discrepancies among these studies. Nonetheless, taken together, each of these studies demonstrates that unlike liver, in which fasting and other forms of undernutrition profoundly depress IGF-I expression, brain IGF-I expression is not dramatically suppressed by undernutrition. The most significant alterations in brain IGF-I expression that we observed occurred in the first 2 wk of life, indicating that nutritional regulation of brain IGF-I expression is developmentally dependent.

The mechanisms that mediate the decrease in hepatic IGF-I expression induced by undernutrition have been subjected to considerable scrutiny, but they have yet to be totally clarified, likely because multiple mechanisms both at and beyond the level of transcription appear to be operative. In addition to reducing IGF-I gene transcription (23), undernutrition also has major posttranscriptional effects, such as altered nuclear RNA splicing, differential expression of specific IGF-I transcripts, and reduced RNA stability leading to more rapid RNA degradation (27-30). Further studies are necessary to understand how nutritional regulation of IGF-I expression differs between the liver and the developing brain. This study did not address whether the changes in IGF-I mRNA abundance are accompanied by similar changes in IGF-I protein abundance. Our findings of moderate (not statistically significant) undernutrition-induced reductions in CB IGF-I mRNA during the first 2 wk of postnatal life, however, are consistent with the work of others demonstrating similar reduction in IGF-I protein in the $\mathrm{CB}$ of undernourished rats (31).

How nutrition signals developmental and regional changes in IGF-I expression also is not clear. One possibility is that changes in brain IGF-I mRNA are not the direct consequence of undernutrition, but are modulated by other factors or hormones affected by nutritional deprivation. Thyroid hormones, as well as thyroid hormone actions, are influenced by nutritional status $(2,9,32)$ and hypothyroidism causes a reduction in serum IGF-I levels $(33,34)$. It is, therefore, possible that reduced thyroid hormone levels or actions related to undernutrition alter brain IGF expression. Differences in the regional distribution of thyroid hormone receptors in the brain could explain the differing response of specific regions to nutritional deprivation during development.

In conclusion, our findings suggest that nutrition regulates IGF-I expression during murine brain development, and that it does so in a manner that is different from that in liver. Nutritional regulation of IGF-I expression in the brain appears to depend on the developmental age and the site of expression. The most significant change in IGF expression occurs in the first 2 wk of postnatal period when brain is more vulnerable to nutritional insult, and the increases in IGF-I expression, as well as the relative preservation of IGF-I expression, may serve in part to protect the brain from injury. Many other factors, however, undoubtedly influence the impact of undernutrition on regional brain growth. Nonetheless, our study suggests that the magnitude and the ontogeny of IGF-I expression play a role in determining the severity of consequences of undernutrition.

Acknowledgments. The authors thank Dr. Dionisios Chrysis for his help in preparation of the IGF-I probe.

\section{REFERENCES}

1. Bedi KS, Warren MA 1988 Effects of nutrition on cortical development. In: Peters A, Jones EG (eds) Cerebral Cortex. Plenum Press, New York, pp 441-477

2. Balasz R, Jordan T, Lewis PD, Patel AJ 1986 Undernutrition and brain development. In: Falkner F, Tanner JM (eds) Human Growth. Plenum Press, New York, pp 415-474

3. Clos J, Favre C, Seme-Matrat M, Legrand J 1977 Effects of undernutrition on cell formation in the rat brain and specifically on cellular composition on the cerebellum. Brain Res 12-26

4. Bedi KS 1991 The effect of undernutrition during early life on granule cell numbers in rat dentate gyrus. J Comp Neurol 311:425-433

5. Brock JW, Prasad C 1992 Alterations in dendritic spine density in rat brain associated with protein malnutrition. Brain Res 66:266-269 
6. Cragg BC 1972 The development of cortical synapses during starvation in the rat. Brain 95:143-150

7. Wiggins RC 1984 Myelin development and nutritional insufficiency. Brain Res Rev 4:151-175

8. Dobbing J 1981 The later development of the brain and its vulnerability. In: Davis JA Dobbing J (eds) Scientific Foundation of Pediatrics. University Park Press, Baltimore, pp 744-759

9. Thissen J-P, Ketelslegers J-M, Underwood LE 1994 Nutritional regulation of the insulin-like growth factors. Endocr Rev 15:80-101

10. Lowe Jr WL, Adamo M, Werner H, Roberts Jr CT, LeRoith D 1989 Regulation by fasting of rat insulin-like growth factor I and its receptor: effects on gene expression and binding. J Clin Invest 84:619-626

11. Sjogren K, Liu JL, Blad K, Skrtic S, Vidal O, Wallenius V, LeRoith D, Tornell J, Isaksson OG, Jansson JO, Ohlsson C 1999 Liver-derived insulin-like growth factor I (IGF-I) is the principal source of IGF-I in blood but is not required for postnatal body growth in mice. Proc Natl Acad Sci USA 96:7088-7092

12. Hintz RL, Suskind R, Amatayakul K, Thanangkul O, Olson R 1978 Plasma somatomedin and growth hormone values in children with protein-calorie malnutrition. J Pediatr 92:153-156

13. Rotwein P, Burgess SK, Milbrandt JD, Krause JE 1988 Differential expression of insulin-like growth factor genes in rat central nervous system. Proc Natl Acad Sci USA 85:265-269

14. Mathews LS, Hammer RE, Behringer RR, D'Ercole AJ, Bell GI, Brinster RL, Palmiter RD 1988 Growth enhancement of transgenic mice expressing human insulin-like growth factor I. Endocrinology 123:2827-2833

15. Behringer RR, Lewin TM, Quaife CJ, Palmiter RD, Brinster RL, D'Ercole AJ 1990 Expression of insulin-like growth factor I stimulates normal somatic growth in growth hormone-deficient transgenic mice. Endocrinology 127:1033-1040

16. Ye P, Carson J, D'Ercole AJ 1995 In vivo actions of insulin-like growth factor(IGF-I) on brain myelination: studies of IGF-I and IGF binding protein-1 (IGFBP-1) transgenic mice. J Neurosci 15:7344-7356

17. Gutierrez-Ospina G, Calikoglu AS, Ye P, D'Ercole AJ 1996 In vivo effects of insulin-like growth factor-I (IGF-I) on the development of sensory pathways: analysis of the primary somatic sensory cortex (S1) of transgenic mice. Endocrinology 137:5484-5492

18. D'Ercole AJ, Dai Z, Xing Y, Boney C, Wilkie MB, Lauder JM, Han VK, Clemmons DR 1994 Brain growth retardation due to the expression of human insulin like growth factor binding protein-1 in transgenic mice: an in vivo model for the analysis of IGF function in the brain. Dev Brain Res 82:213-222

19. Ni W, Rajkumar K, Nagy JI, Murphy LJ 1997 Impaired brain development and reduced astrocyte response to injury in transgenic mice expressing IGF binding protein-1. Brain Res 769:97-107

20. Carson MJ, Behringer RR, Brinster RL, McMorris FA 1993 Insulin-like growth factor I increases brain growth and central nervous system myelination in transgenic mice. Neuron 10:729-740
21. Lee K-H, Calikoglu AS, Ye P, D'Ercole AJ 1999 Insulin-like growth factor-I (IGF-I) ameliorates and IGF binding protein-1 (IGFBP-1) exacerbates the effects of undernutrition on brain growth during early postnatal life: studies in IGF-I and IGFBP-1 transgenic mice. Pediatr Res 45:331-336

22. Bedi KS 1984 Effects of undernutrition on brain morphology: a critical review of methods and results. In: Jones DG (ed) Current Topics on Research on Synapses, Vol 2. Alan R. Liss, New York, pp 93-163

23. Straus DS, Takemoto CD 1991 Specific decrease in liver insulin-like growth factor-I and brain insulin-like growth factor-II gene expression in energy-restricted rats. J Nutr 121:1279-1286

24. Emler CA, Schalch DS 1987 Nutritionally-induced changes in hepatic insulin-like growth factor I (IGF-I) gene expression in rats. Endocrinology 120:832-834

25. Moats-Staats BM, Brady Jr JL, Underwood LE, D'Ercole AJ 1989 Dietary protein restriction in artificially reared neonatal rats causes a reduction of insulin-like growth factor-I gene expression. Endocrinology 125:2368-2374

26. Bornfeldt KE, Arnqvist HJ, Enberg B, Mathews LS, Norstedt G 1989 Regulation of insulin-like growth factor-I and growth hormone receptor gene expression by diabetes and nutritional state in rat tissues. J Endocrinol 122:651-656

27. Pell JM, Saunders JC, Gilmour RS 1993 Differential regulation of transcription initiation from insulin-like growth factor-I (IGF-I) leader exons and of tissue IGF-I expression in response to changed growth hormone and nutritional status in sheep. Endocrinology 132:1797-1807

28. Adamo ML, Ben-Hur H, Roberts Jr CT, LeRoith D 1991 Regulation of start site usage in the leader exons of the rat insulin-like growth factor-I gene by development, fasting, and diabetes. Mol Endocrinol 5:1677-1686

29. Zhang J, Whitehead Jr RE, Underwood LE 1997 Effect of fasting on insulin-like growth factor (IGF)-IA and IGF-IB messenger ribonucleic acids and prehormones in rat liver. Endocrinology 138:3112-3118

30. Zhang J, Chrysis D, Underwood LE 1998 Reduction of hepatic insulin-like growth factor I (IGF-I) messenger ribonucleic acid (mRNA) during fasting is associated with diminished splicing of IGF-I pre-mRNA and decreased stability of cytoplasmic IGF-I mRNA. Endocrinology 139:4523-4530

31. Shambaugh 3rd GE, Natarajan N, Davenport ML, Oehler D, Unterman T 1995 Nutritional insult and recovery in the neonatal rat cerebellum: insulin-like growth factors (IGFs) and their binding proteins (IGFBPs). Neurochem Res 20:475-490

32. Danforth E, Burger AG 1989 The impact of nutrition on thyroid hormone physiology and action. Annu Rev Nutr 9:201-227

33. Marek J, Schullerova M, Schreiberova O, Limanova Z 1981 Effect of thyroid function on serum somatomedin activity. Acta Endocrinol 96:491-497

34. Miell JP, Taylor AM, Zini M, Maheshwari HG, Ross RJM, Valcavi R 1993 Effects of hypothyroidism and hyperthyroidism on insulin-like growth factors and growth hormone on IGF binding proteins. J Clin Endocrinol Metab 76:950-955 